\title{
Diasteroselective Colloidal Self-Assembly Affects the Immunological Response of the Molecular Adjuvant Sulfavant
}

\author{
Emiliano Manzo, ${ }^{*},, \| \oplus$ Carmela Gallo, ${ }^{\dagger, \|}$ Laura Fioretto, ${ }^{\dagger, \S}$ Genoveffa Nuzzo, ${ }^{\dagger}$ (1) Giusi Barra, ${ }^{\dagger}$ \\ Dario Pagano, ${ }^{\dagger}$ Irene Russo Krauss, ${ }^{\S}$ Luigi Paduano, ${ }^{\S}$ Marcello Ziaco, ${ }^{\dagger}$ Marina DellaGreca, ${ }^{\S}$ \\ Raffaele De Palma, ${ }^{\ddagger}$ and Angelo Fontana* ${ }^{*}+$ (0) \\ ${ }^{\dagger}$ Bio-Organic Chemistry Unit, CNR-Institute of Biomolecular Chemistry, Via Campi Flegrei 34, Pozzuoli, 80078 Napoli, Italy \\ ${ }^{\sharp}$ Dept. of Precision Medicine, Second University of Naples, c/o II Policlinico (Bd. 3), Via Pansini 5, 80131 Napoli, Italy \\ ${ }^{\S}$ Department of Chemical Sciences, University of Naples Federico II, Via Cinthia 4, 80136 Napoli, Italy
}

\section{Supporting Information}

ABSTRACT: Adjuvants are components of vaccine that enhance the specific immune response against co-inoculated antigens. Recently, we reported the characterization of a synthetic sulfolipid named Sulfavant A (1) as a promising candidate of a novel class of molecular adjuvants based on the sulfoquinovosyl-diacylglycerol skeleton. Here, we report an improved synthesis of the sulfolipid scaffold, as well as the preparation of two analogs named Sulfavant-S (2) and Sulfavant-R (3) with enhanced property to modulate master immune targets such as human dendritic cells (DCs). According to the present approach, synthesis of 1 is reduced from 14 to 11 steps with nearly triplication of the overall yield (11\%). The new members 2 and 3 elicit DC maturation at a concentration of $10 \mathrm{nM}$, which is 1000 times more potent than the parent molecule $\mathbf{1}$. Analysis of dynamic light scattering

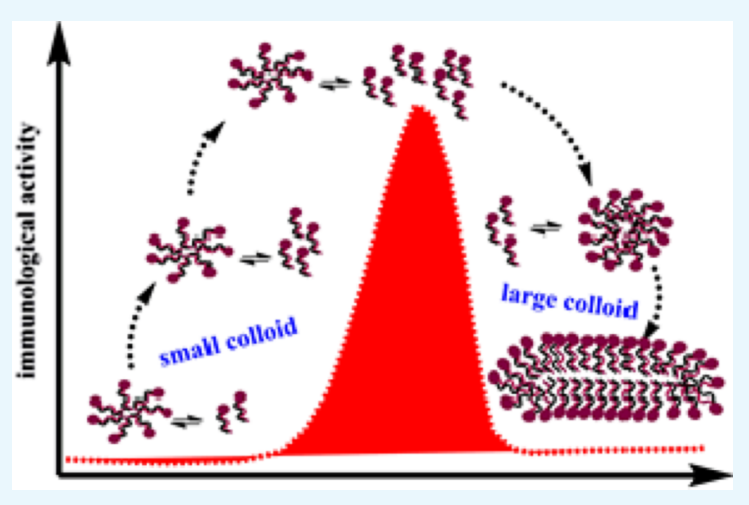
indicates self-assembly of Sulfavants and formation of colloidal particles with a small hydrodynamic radius $(50 \mathrm{~nm})$ for the epimers 2 and 3 and a larger radius $(150 \mathrm{~nm})$ for 1 . The colloidal aggregates are responsible for the bell-shaped dose-response curve of these products. We conclude that the particle size also affects the equilibrium with free monomers, thus determining the effective concentration of the sulfolipid molecule at the cellular targets and the different immunological efficacy of $1-3$. Sulfavants $(1-3)$ do not show in vitro cytotoxicity at concentrations $10^{5}$ higher than the dose that triggers maximal immune response, thus predicting a low level of toxicological risk in their formulation in vaccines.

\section{INTRODUCTION}

Adjuvants are aspecific components of vaccines that improve the capacity of the immune system to build a long standing and efficient response to antigens. Adjuvants achieve these effects through different mechanisms, including modulation of $\mathrm{T}$ helper subsets. ${ }^{1-4}$ In the last years, there has been a considerable effort to introduce a rational approach to the identification of novel adjuvants that increase safety of vaccines and reinforce the immune response in weakened immune patients. ${ }^{5-10}$

A major breakthrough of these studies has been the identification of pathogen-associated molecular patterns and the characterization of antigen-presenting cells (APCs) as convenient targets of novel molecules or delivery systems. ${ }^{11}$ Sulfavant A (1) is a synthetic sulfolipid that activates human dendritic cells (DCs), a specific type of APCs that operate as master regulators of the initiation of adaptive immune response. Exposure of cultured DC to Sulfavant A (1) triggers the transformation of DC to the "mature" stage with upregulation of T-cell co-stimulatory factors (HLA-DR, CD83, CD86) and expression of specific cytokine subsets (e.g., IL-12p40 and INF- $\gamma) .{ }^{12}$ In mice, this process induced antigen-specific immunization with antibody titers that are comparable to traditional adjuvants (e.g., TiterMax). In agreement with these results, vaccination with hgp 10 peptide antigen and Sulfavant $A$ elicited a protective response with reduction of tumor growth and increase of survival in the murine B16 melanoma model. ${ }^{12}$

Although the mechanism has not been fully elucidated, activity of Sulfavant A (1) is independent of toll-like receptor 2 and $4 .^{12}$ This marks a clear difference with other glycolipid adjuvants (e.g., monophosphoryl lipid A) currently under investigation ${ }^{13-18}$ and suggests that the sulfoquinovosylglycerol backbone may be a distinctive trait of a novel family of immunomodulators. ${ }^{19}$ The aim of the present study was the additional characterization of the chemical determinants that affect the biological activity of this group of molecular adjuvants, as well as the preparation of new analogs with a higher immune

Received: November 27, 2018

Accepted: January 30, 2019

Published: April 30, 2019 
Scheme 1. Improved Synthesis of Sulfavant A (1)

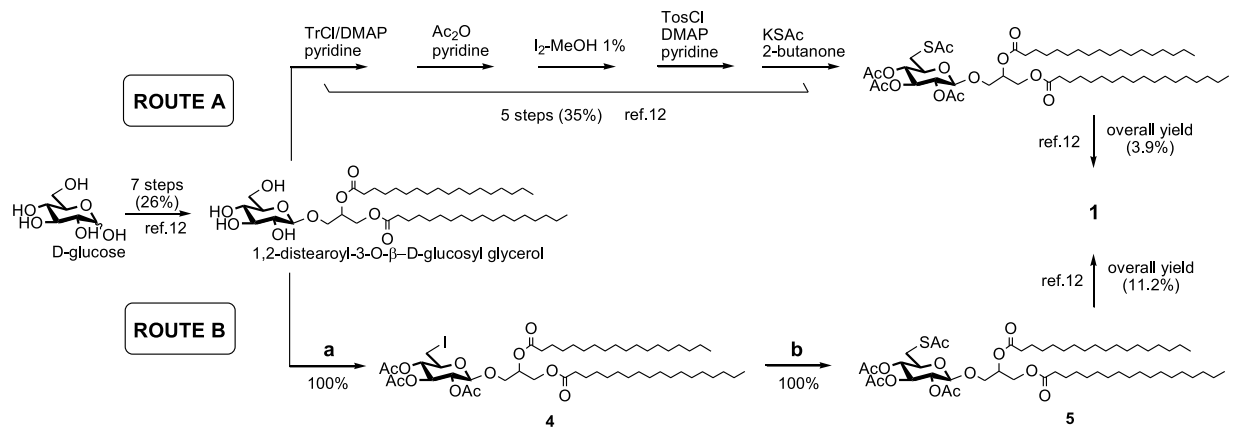

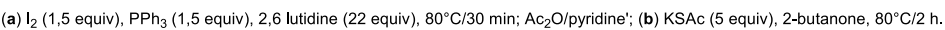

Scheme 2. Synthesis of Sulfavant S (2) and Sulfavant R (3); (a) $\mathrm{I}_{2}$ (1.5 equiv), $\mathrm{PPh} 3$ (1,5 equiv), 2,6-Lutidine (22 equiv), $80{ }^{\circ} \mathrm{C} /$ $30 \mathrm{~min}$; $\mathrm{Ac}_{2} \mathrm{O} /$ Pyridine; (b) KSAc (5 equiv), 2-Butanone, $80^{\circ} \mathrm{C} / 2 \mathrm{~h}$; If Not Stated Otherwise, Steps Are Identical to Those Described in Ref 12

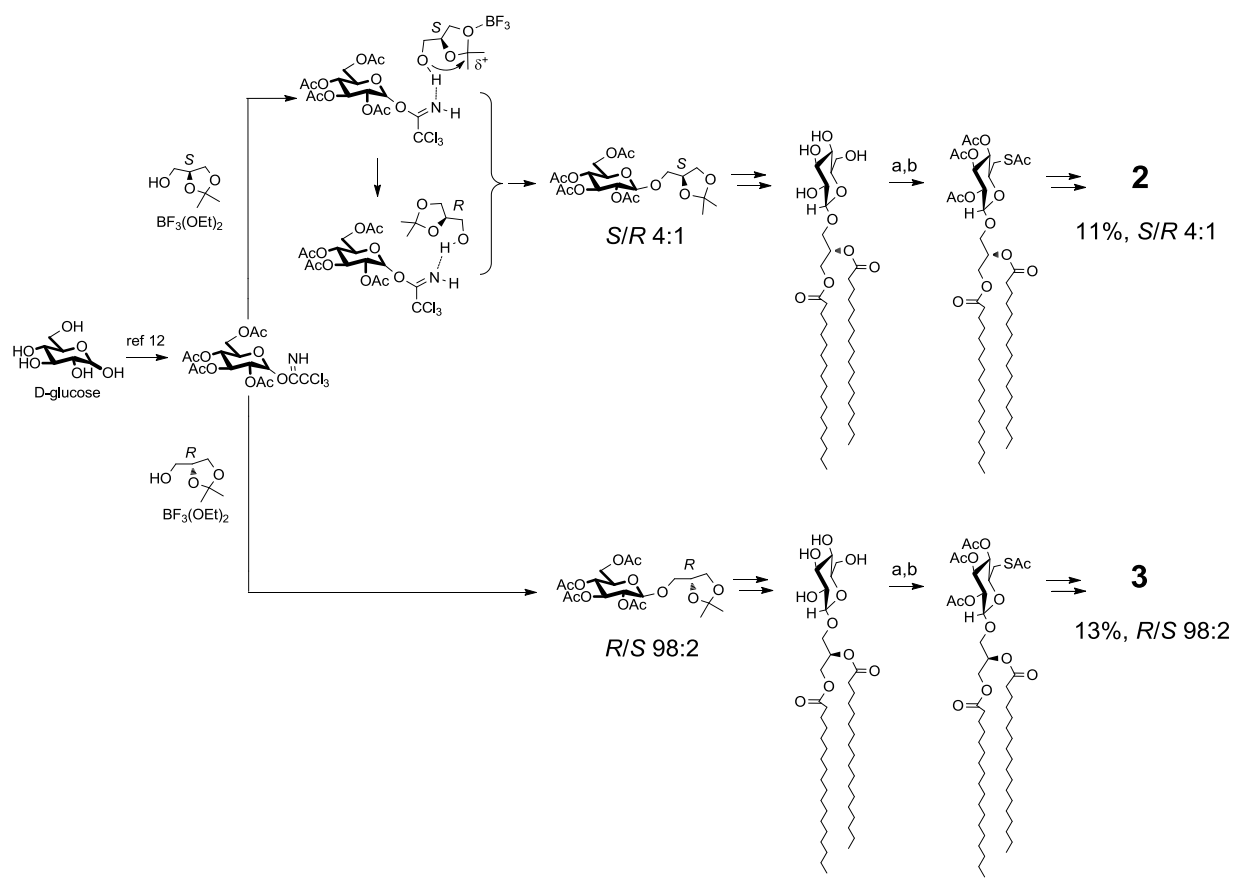

efficacy. Here, we report a new synthetic strategy of the sulfolipid scaffold and synthesis of two epimers, named Sulfavant-S (2) and Sulfavant-R (3), that induce maturation and cytokine gene expression of DCs at nanomolar concen-

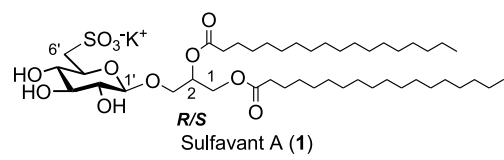

\section{RESULTS AND DISCUSSION}

Sulfavant A (1) is an epimeric mixture at C-2 (R/S about 1.3:1) of $\beta$-sulfoquinovoside-distearoyl glycerol that is prepared starting with acetylation of D-glucose, followed by selective deacetylation of the anomeric hydroxyl group with benzylamine. Coupling with $1,2-O$-isopropylidene glycerol by trichloroacetimidate methodology gave $3-O-\left(2^{\prime}, 3^{\prime}, 4^{\prime}, 6^{\prime}\right.$-tetra-acetyl $)-\beta$-D- trations. We also show that these compounds form colloidal nanoparticle aggregates that are first responsible of the difference in the cellular response to $\mathbf{1 - 3}$.
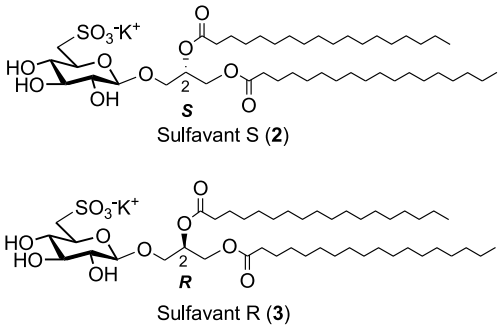

glucosyl-glycerol that was after derivatized by stearoyl groups to obtain the key intermediate 1,2-distearoyl-3- $O-\beta$-D-glucosyl glycerol. $^{12,19}$ In the original work (route A of Scheme 1), ${ }^{12,19 a}$ sulfonation at carbon- $6^{\prime}$ of glucose was achieved by multiple steps of protection and deprotection that affected negatively the overall synthetic yield. In order to overtake this issue, we tested 


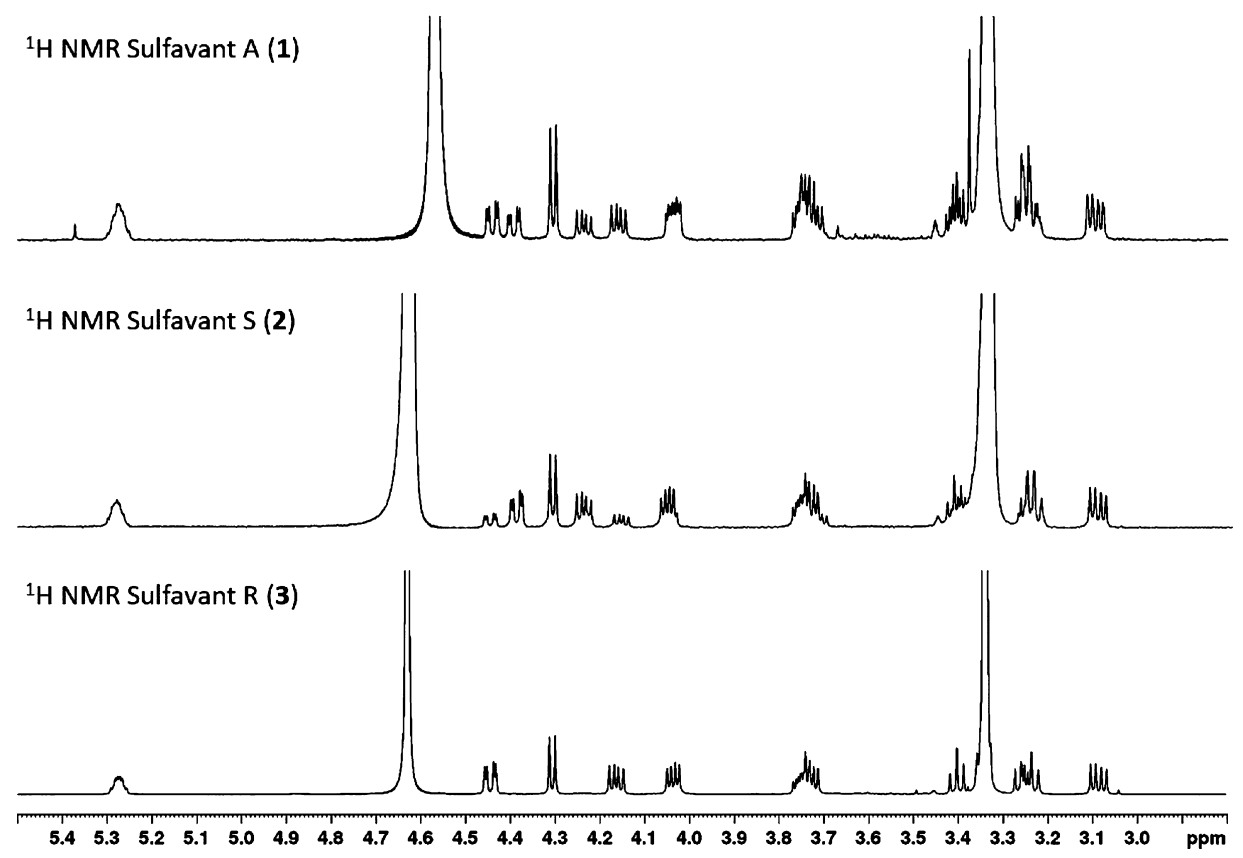

Figure 1. ${ }^{1} \mathrm{H}$ NMR $\left(400 \mathrm{MHz}, \mathrm{CD}_{3} \mathrm{OD} / \mathrm{CDCl}_{3} 1 / 1\right)$ spectra of $1-3$. Partial epimerization of Sulfavant $\mathrm{S}(2)$ is clearly detectable by the presence of the double doublets at 4.45 and $4.17 \mathrm{ppm}$ due to the $\mathrm{R}$ epimer.

the direct sulfonation of the $6^{\prime}$-carbon through an iodinate derivative in agreement with Traboni and co-workers. ${ }^{20}$

With Sulfavant A (1), iodination of 1,2-distearoyl-3-O- $\beta$-Dglucosyl glycerol followed by conversion to thioacetate reduced the number of steps from 14 to 11 , as well as triplicated the overall yield from 4 to $11.2 \%$ (route B of Scheme 1). The new approach preserved the versatility of the original synthesis and was also tested on the preparation of the two epimers Sulfavant $S$ (2) and Sulfavant R (3) from $(S)$ - or (R)-1,2-O-isopropilidene glycerol, respectively (Scheme 2 ).

As depicted in Scheme 2, the single stereoisomers were both prepared with overall yield higher than $10 \%$. MS and NMR data of the two new products were identical to Sulfavant A (1) in all aspects but for the signals of the protons $\mathrm{H}_{2}-1$ that fall at $\delta 4.40$ $(1 \mathrm{H}, \mathrm{dd}, J=2.7,12.0 \mathrm{~Hz}, \mathrm{H}-1 \mathrm{a})$ and $4.24(1 \mathrm{H}, \mathrm{dd}, J=6.9,12.0$ $\mathrm{Hz}, \mathrm{H}-1 \mathrm{~b})$ in the $\mathrm{S}$ epimer $(2)$ and at $\delta 4.45(1 \mathrm{H}, \mathrm{dd}, J=2.6,12.1$ $\mathrm{Hz}, \mathrm{H}-1 \mathrm{a})$ and $4.17(1 \mathrm{H}, \mathrm{dd}, J=6.7,12.1 \mathrm{~Hz}, \mathrm{H}-1 \mathrm{~b})$ in the $\mathrm{R}$ epimer (3) (Figure 1). While the stereochemistry of 3 is preserved throughout the sequence of reactions, synthesis of $\mathbf{2}$ showed a partial epimerization of C-2 due to the diastereoselective opening and subsequent closure of the acetonide during the coupling step. Therefore, Sulfavant S (2) was composed of a mixture of $4: 1 \mathrm{~S} / \mathrm{R}$ diastereomers at C-2 of glycerol (Scheme 2) and, in this respect, it was similar to Sulfavant A (1) but with a different diastereomeric ratio (S/R about 1:1.3).

The new analogs up-regulated expression of the maturation markers HLA-DR, CD83, and CD86 at $10 \mathrm{nM}$ (Figure 2). This was drastically different from the reported response to Sulfavant A (1) that triggers clear differentiation only of the CD83 + DC population at $10 \mu \mathrm{M} .{ }^{12}$ The activity of both epimers decreased at the higher concentrations even if Sulfavant S (2) stimulated residual overexpression of CD83 in the whole range. CD83 is highly expressed on mature DCs and is not detectable in other APCs that do not prime naive T cells. Thus, CD83 + DCs are considered a hallmark of the ability to prime a protective $\mathrm{T}$ cell response and have a profound clinical implication for vaccines against many widespread infectious diseases, including HIVAIDS, malaria, and tuberculosis, or for therapeutic treatment of cancers. $^{11}$

After 24 h, compounds 2 and the 3 also enhanced IL-12p40 gene expression (Figure 3 ) and no effect on expression of IL-10. IL-12 is a pro-inflammatory cytokine released by DC in response to infection of bacteria and virus, ${ }^{21,22}$ whereas IL-10 downregulates immune and inflammatory response and mediates many of the tolerogenic effects exerted by DCs. ${ }^{23,24}$ On the whole, the effect of $\mathbf{2}$ and $\mathbf{3}$ on these cytokines is qualitatively similar to the results previously reported with Sulfavant-A (1) even if the new analogs 2 and 3 gave a maximal activation at 10 $\mathrm{nM}$, whereas 1 showed the strongest effect only at $10 \mu \mathrm{M} .^{12}$ As previously noted for the surface markers, IL-12p40 expression decreased with the increase of the concentration of both epimers and only 2 conserved a residual activity at $10 \mu \mathrm{M}$. Compounds 1-3 did not show toxic activity on DCs and other primary cells at concentration up to $10^{5}$ times higher than the effective dose (Supporting Information Figure S5).

These tests indicate that $\mathbf{1 - 3}$ are all safe DC activators but also underline a divergent response that correlates with stereochemical aspects, as the diastereomixture 2 (S/R 4:1) and the diastereopure 3 are significantly more potent than their epimeric mixture 1 ( $\mathrm{S} / \mathrm{R}$ about $1: 1.3$ ). As reported by diagnostic expression of CD83 (Figure 4A), efficacy of single epimers 2 and 3 did not increase sigmoidally with concentration but followed a typical "bell-shaped" curve with decrease of activity above 10 nM. A similar response is also observable with Sulfavant A (1) but only at a concentration higher than $10 \mu \mathrm{M}$. Bell-shaped dose-response curves are not the rule but several drugs show this behavior. Recently, occurrence of colloidal species has been related to the biological response of these products. ${ }^{25}$ Colloidal properties are also reported to affect biological activity ${ }^{26-29}$ and chemical reactivity $^{30}$ of sulfoquinovosides in aqueous or polar environment.

DLS is commonly used for the analysis of supramolecular lipid aggregation. ${ }^{31}$ Figure $4 \mathrm{~B}$ shows the hydrodynamic radius of the 
A)
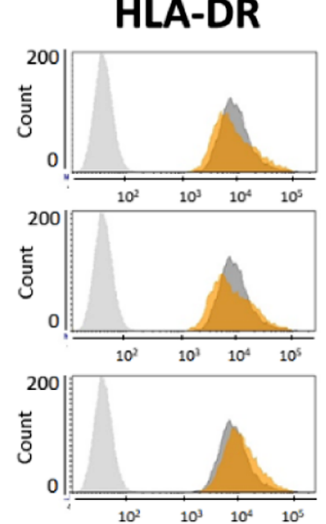

B)
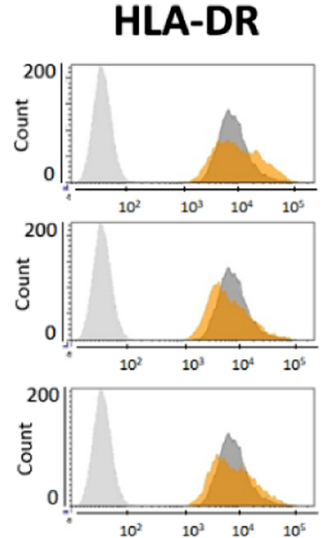

C)
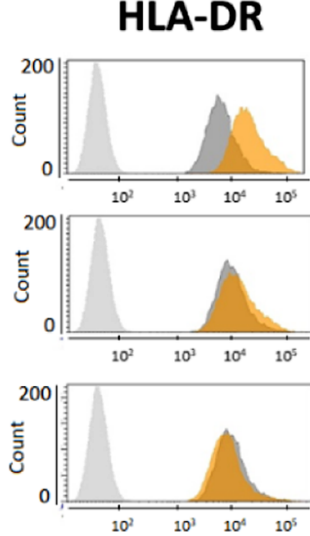

CD86
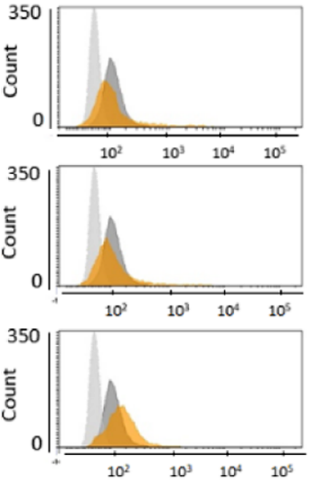

CD86
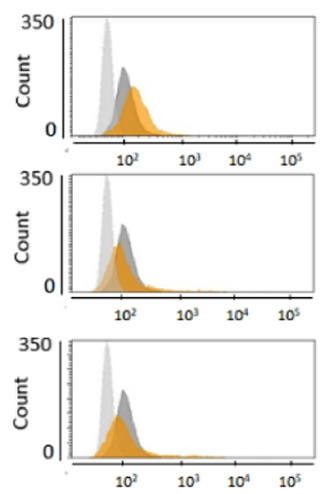

CD86
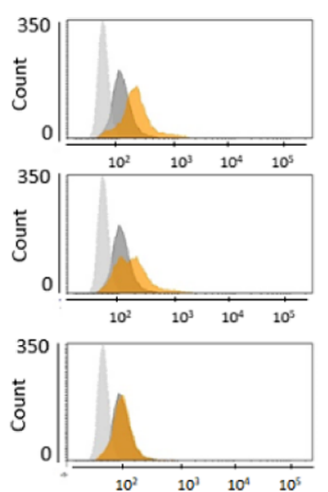

CD83
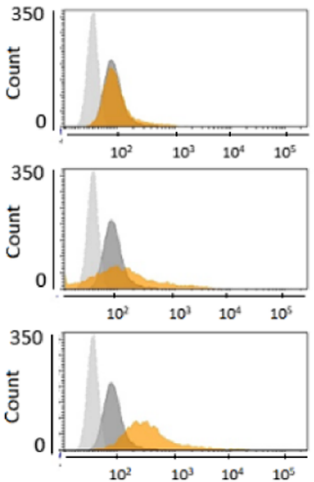

$10 \mu \mathrm{M}$

$10 \mathrm{nM}$

$100 \mathrm{nM}$

\section{CD83}

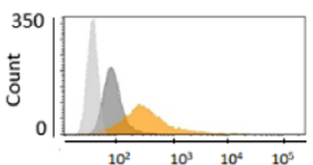

$10 \mathrm{nM}$

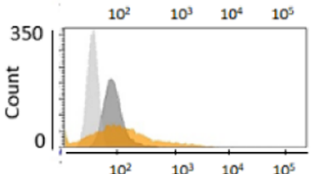

$100 \mathrm{nM}$

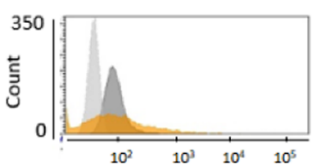

$10 \mu \mathrm{M}$

Figure 2. Flow-cytometry analysis of maturation phenotyping markers (HLA-DR, CD86, CD83) in moDCs stimulated with (A) Sulfavant A (1), (B) Sulfavant S (2), and (C) Sulfavant R (3) at concentrations of $0.01,0.1$, and $10 \mu \mathrm{M}$; gray = isotype control; dark gray = unstimulated cells; orange = stimulated.

aggregates of $1-3$ at $0.2 \mathrm{mM}$ in Milli-Q water as measured by DLS. Sulfavant S (2) and R (3) have a smaller hydrodynamic radius (around $50 \mathrm{~nm}$ ), whereas the self-aggregation of Sulfavant A (1) led to vesicles of $150 \mathrm{~nm}$ with higher size dispersity. Surface tension measurements performed with Sulfavant A, S, and $R(1-3)$ further highlighted the marked difference between the aggregation behaviors of these molecules. Indeed, analysis of the surface tension as a function of concentrations of 1-3 showed a different slope in the premicellar region with indication of a minimum surface area per molecule (Amin) larger for Sulfavant A (1) than for Sulfavant S (2) and R (3).

These data proved a different supramolecular organization among 1-3 in water, as well as a remarkable parallelism between self-aggregation behavior and biological response. In agreement with Shoichet and co-workers, ${ }^{25}$ we suggest that formation of colloidal particles of Sulfavants reduces the activity because it affects the effective concentration of the free sulfolipids at the target site. In line with this view, we suggest that the concentration of free monomers is higher with the small colloidal aggregates made by the epimers 2 and 3, whereas it is lower with the larger aggregates of Sulfavant A (1) (Figure 5). With the increase of the concentration, the size of both colloid particles change and the monomers are tied up, thus leading to the bell-shaped curves measured experimentally around $10 \mathrm{nM}$ with 2 and 3 and around $10 \mu \mathrm{M}$ with 1 . 


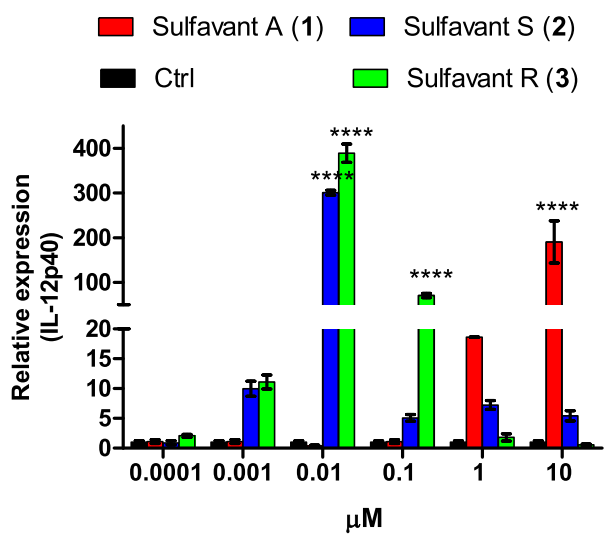

Figure 3. Gene expression analysis of IL-12p40 in DCs by stimulation with increasing dose of Sulfavants 1-3. Asterisks indicate significant differences from the control group at a $95 \%(P<0.05)$ confidence level, as determined using two-way ANOVA analysis.

\section{CONCLUSIONS}

Modern vaccines are no longer made with inactivated or attenuated pathogens, indeed they use pathogen-related proteins obtained by molecular biology techniques. Therefore, all vaccines require adjuvants to stimulate innate immune cells or additional receptors on lymphocytes such as complement receptors. ${ }^{32}$ Here, we report an enhancement of the synthesis and activity of immunomodulatory compounds based on the sulfoquinovoside-glycerol skeleton. The two new analogs, Sulfavant S (2) and Sulfavant R (3), trigger maturation of the innate immune DCs at $10 \mathrm{nM}$, which is 3 orders of magnitude lower than the prototype molecule Sulfavant A (1). The increase of the biological potency correlates with the assembling of different colloidal particles that is dependent on diasteropurity of $\mathbf{1}-\mathbf{3}$. We suggest that epimers 2 and $\mathbf{3}$ can form aggregates smaller and less "cohesive", thus in equilibrium with a "more effective" fraction of monomers that can freely diffuse and interact with cell targets. The colloid hypothesis also well explains the bell-shaped dose-response curve that seems to be typical of this family of compounds. Notably, it has been already reported that stereochemical characteristics can determine the supramolecular organization of amphipathic substances and change the biological activity by interfering with interaction and binding affinity with protein and cellular structures. ${ }^{33-37}$ DCs are emerging as a critical cell type in controlling the immune response; therefore, the stimulation of DC by Sulfavants must be considered a promising feature to generate therapeutic vaccines and, in view of in vivo tests, the formation of stable self- aggregates and the absence of in vitro toxic effects are predictive of a low level of toxicological risk.

\section{EXPERIMENTAL SECTION}

General Experimental Procedures. NMR spectra were recorded on a Bruker AVANCE-400 (400.13 MHz). HR-MS spectra were acquired by a $\mathrm{Q}$ Exactive Hybrid QuadrupoleOrbitrap mass spectrometer (Thermo Scientific). TLC plates (Kieselgel $60 \mathrm{~F}_{254}$ ) and silica gel powder (Kieselgel 60, 0.063$0.200 \mathrm{~mm}$ ) were from Merck.

All the reagents were purchased from Sigma-Aldrich and used without any further purification. DLS measurements were performed with a home-made instrument composed by a Photocor compact goniometer, an SMD 6000 Laser Quantum $50 \mathrm{~mW}$ light source operating at $5325 \AA$, a photomultiplier (PMT-120-OP/B), and a correlator (Flex02-01D, correlator.com). The surface tension of aqueous Sulfavant samples was measured with a Sigma 70 tensiometer (KSV, Stockholm, Sweden) using the Du Noüy ring method.

1,2-O-Isopropilidene-3-O-[(2',3', $4^{\prime}, 6^{\prime}$-tetra-O-acetyl)$\boldsymbol{\beta}$-D-glucosyl]-S-glycerol. ${ }^{1} \mathrm{H} \mathrm{NMR}\left(400 \mathrm{MHz} \mathrm{CDCl}_{3}\right): \delta$ $5.19\left(1 \mathrm{H}, \mathrm{bt}, J=9.4 \mathrm{~Hz}, \mathrm{H}-3^{\prime}\right), 5.06\left(1 \mathrm{H}, \mathrm{bt}, J=9.9 \mathrm{~Hz}, \mathrm{H}-4^{\prime}\right)$, $4.99\left(1 \mathrm{H}, \mathrm{bt}, J=8.4 \mathrm{~Hz}, \mathrm{H}-2^{\prime}\right), 4.60\left(1 \mathrm{H}, \mathrm{d}, J=7.8 \mathrm{~Hz}, \mathrm{H}-1^{\prime}\right)$, $4.25(1 \mathrm{H}, \mathrm{dd}, J=5.0,12 \mathrm{~Hz}, \mathrm{H}-1 \mathrm{a}), 4.14-3.69$ (6H, overlapped, $\left.\mathrm{H}-1 \mathrm{~b}, \mathrm{H}-2, \mathrm{H}_{2}-6^{\prime}, \mathrm{H}-5^{\prime}, \mathrm{H}-3 \mathrm{a}\right), 3.62$ ( $1 \mathrm{H}, \mathrm{dd}, \mathrm{J}=5.9,10.7 \mathrm{~Hz}, \mathrm{H}-$ 3b), 2.08 (3H, s, OAc), 2.04 (3H, s, OAc), 2.01 (3H, s, OAc), $1.99(3 \mathrm{H}, \mathrm{s}, \mathrm{OAc}), 1.40\left(3 \mathrm{H}, \mathrm{s}, \mathrm{CH}_{3}\right), 1.33\left(3 \mathrm{H}, \mathrm{s}, \mathrm{CH}_{3}\right)$; the spectrum ${ }^{1} \mathrm{H}$ NMR showed traces of signals related to the epimer R; HRESIMS $m / z$ : $485.1639[\mathrm{M}+\mathrm{Na}]^{+}$(calcd for $\left.\mathrm{C}_{20} \mathrm{H}_{30} \mathrm{O}_{12} \mathrm{Na}, 485.1635\right)$.

1,2-Di-O-stearoyl-3-O- $\boldsymbol{\beta}$-D-glucosyl-S-glycerol. ${ }^{1} \mathrm{H}$ NMR (400 MHz, $\left.\mathrm{CDCl}_{3}\right): \delta 5.24(1 \mathrm{H}, \mathrm{m}, \mathrm{H}-2), 4.38(1 \mathrm{H}$, dd, $J=2.5,12.0 \mathrm{~Hz}, \mathrm{H}-1 \mathrm{a}), 4.29\left(1 \mathrm{H}, \mathrm{d}, J=7.5 \mathrm{~Hz}, \mathrm{H}-1^{\prime}\right), 4.16$ $(1 \mathrm{H}, \mathrm{dd}, J=6.7,12.0 \mathrm{~Hz}, \mathrm{H}-1 \mathrm{~b}), 3.88(1 \mathrm{H}, \mathrm{dd}, J=5.1,10.6 \mathrm{~Hz}$, $\mathrm{H}-3 \mathrm{a}), 3.81\left(2 \mathrm{H}, \mathrm{m}, \mathrm{H}_{2}-6^{\prime}\right), 3.68(1 \mathrm{H}, \mathrm{dd}, J=6.9,10.6 \mathrm{~Hz}, \mathrm{H}-$ 3b), $3.55\left(1 \mathrm{H}, \mathrm{bt}, J=9.1 \mathrm{~Hz}, \mathrm{H}-3^{\prime}\right), 3.49(1 \mathrm{H}, \mathrm{bt}, J=9.1 \mathrm{~Hz}, \mathrm{H}-$ $\left.4^{\prime}\right), 3.34\left(1 \mathrm{H}, \mathrm{bt}, J=8.0 \mathrm{~Hz}, \mathrm{H}-2^{\prime}\right), 3.29\left(1 \mathrm{H}, \mathrm{m}, \mathrm{H}-5^{\prime}\right), 2.28$ (4H, overlapped, $\alpha$-methylenes of acyl portions), $1.65-1.52$ (4H, overlapped, $\beta$-methylenes of acyl portions), $1.33-1.19$ (aliphatic methylenes), $0.86\left(6 \mathrm{H}, \mathrm{bt}, \mathrm{J}=6.3 \mathrm{~Hz}, 2 \mathrm{CH}_{3}\right)$; the spectrum ${ }^{1} \mathrm{H}$ NMR showed traces of signals related to the epimer $R$; HRESIMS $m / z$ : $809.6116[\mathrm{M}+\mathrm{Na}]^{+}$(calcd for $\mathrm{C}_{45} \mathrm{H}_{86} \mathrm{O}_{10} \mathrm{Na}$, 809.6119).

1,2-Di-O-stearoyl-3-O-[(2', 3', $4^{\prime}$-tri-O-acetyl-6' -thioacetyl)- $\boldsymbol{\beta}$-D-glucosyl]-S-glycerol. ${ }^{1} \mathrm{H}$ NMR $(400 \mathrm{MHz}$, $\left.\mathrm{CDCl}_{3}\right): \delta 5.19-5.10(2 \mathrm{H}$, overlapped, H-2, H-3'), 4.97-4.88 $\left(2 \mathrm{H}\right.$, overlapped, $\left.\mathrm{H}-2^{\prime}, \mathrm{H}-4^{\prime}\right), 4.47\left(1 \mathrm{H}, \mathrm{d}, J=8.0 \mathrm{~Hz}, \mathrm{H}-1^{\prime}\right)$,
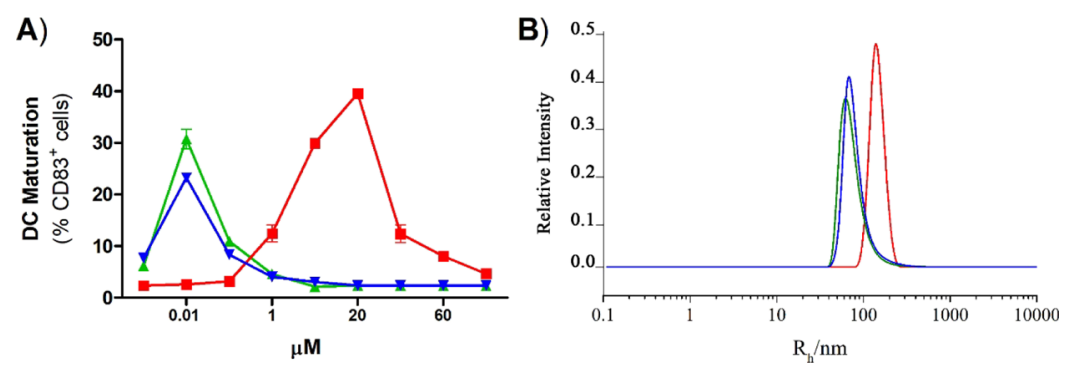

Figure 4. Correlation of immunomodulatory activity vs colloidal behavior of Sulfavants 1-3. (A) Percentage of mature DCs after stimulation by 1-3. Data are expressed as mean and standard deviation from a duplicate of two independent experiments and compared to cells treated only with vehicle (Ctrl). $* * * * P<0.0001$ vs control. (B) Hydrodynamic radius distribution of particles of $1-3$ in aqueous suspension at $0.2 \mathrm{mM}$ as measured by dynamic light scattering (DLS) on three independent measurements. Red = Sulfavant A (1); blue = Sulfavant S (2); green = Sulfavant R (3). 

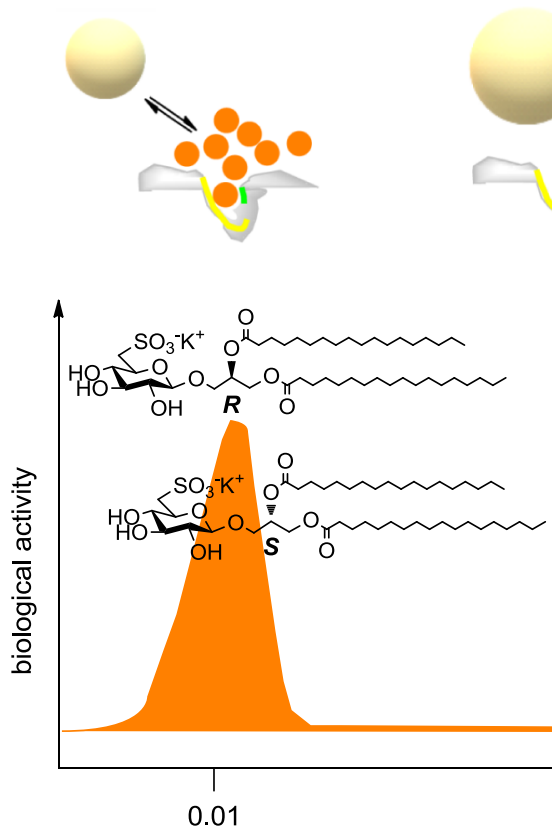

Figure 5. Representation of the proposed colloidal mechanism of action of Sulfavants. Self-association of the sulfolipids into colloidal particles depends on diasteropurity of the organic molecules. With epimers $\mathbf{2}$ and $\mathbf{3}$ (left side), the concentration of free monomers in equilibrium with small aggregates is high and the products occupy effectively the receptor target at very low dose $\left(\mathrm{EC}_{50} 10 \mathrm{nM}\right)$. With the increase of the concentration, there is a gradual loss of the activity leading to a typical bell-shaped dose response curve that we attribute to occurrence of larger colloidal nanoparticles. The epimeric mixture 1 (right side) produces large aggregates that are able to hold the monomers, thus reducing the effective concentration of the monomers and the biological potency $\left(\mathrm{EC}_{50} 10 \mu \mathrm{M}\right)$. Increase of the concentration of $\mathbf{1}$ induces loss of activity for the formation of very large aggregates that cannot interact with the cell target in an effective manner. At the moment, we have no direct cue to explain the dependence of the size of the colloidal aggregates on the diastereomeric purity of the glycerol center. However, it is reasonable that the presence of both epimers can break the symmetry of the packing of the alkyl chains, thus leading to less dense and less tightly packed structures.

$4.27(1 \mathrm{H}, \mathrm{dd}, J=3.5,10.0 \mathrm{~Hz}, \mathrm{H}-1 \mathrm{a}), 4.09(1 \mathrm{H}, \mathrm{dd}, J=6.4,10.0$ $\mathrm{Hz}, \mathrm{H}-1 \mathrm{~b}), 3.88(1 \mathrm{H}, \mathrm{dd}, J=4.7,11.0 \mathrm{~Hz}, \mathrm{H}-3 \mathrm{a}), 3.64(1 \mathrm{H}, \mathrm{dd}, J$ $=5.3,11.0 \mathrm{~Hz}, \mathrm{H}-3 \mathrm{~b}), 3.60\left(1 \mathrm{H}, \mathrm{m}, \mathrm{H}-5^{\prime}\right), 3.22(1 \mathrm{H}, \mathrm{dd}, J=2.4$, $\left.14.3 \mathrm{~Hz}, \mathrm{H}-6^{\prime} \mathrm{a}\right), 3.03\left(1 \mathrm{H}, \mathrm{dd}, J=6.9,14.3 \mathrm{~Hz}, \mathrm{H}-6^{\prime} \mathrm{b}\right), 2.32$ $(3 \mathrm{H}, \mathrm{s}, \mathrm{SAc}), 2.27(4 \mathrm{H}, \mathrm{bt}, J=7.0 \mathrm{~Hz}, \alpha$-methylenes of acyl portions), $2.05(3 \mathrm{H}, \mathrm{s}, \mathrm{OAc}), 2.01(3 \mathrm{H}, \mathrm{s}, \mathrm{OAc}), 1.96(3 \mathrm{H}, \mathrm{s}$, $\mathrm{OAc}), 1.63-1.54(4 \mathrm{H}$, overlapped, $\beta$-methylenes of acyl portions), $1.32-1.19$ (aliphatic methylenes), $0.85(6 \mathrm{H}, \mathrm{bt}, J=$ $6.2 \mathrm{~Hz}, 2 \mathrm{CH}_{3}$ ); the spectrum ${ }^{1} \mathrm{H}$ NMR showed traces of signals related to the epimer $R$; HRESIMS $m / z: 993.6302[\mathrm{M}+\mathrm{Na}]^{+}$ (calcd for $\mathrm{C}_{53} \mathrm{H}_{94} \mathrm{NaO}_{13} \mathrm{~S}, 993.6313$ ).

1,2-O-Isopropilidene-3-O-[(2', $\mathbf{3}^{\prime}, 4^{\prime}, 6^{\prime}$-tetra-O-acetyl)$\boldsymbol{\beta}$-D-glucosyl]- $\boldsymbol{R}$-glycerol. ${ }^{1} \mathrm{H}$ NMR $\left(400 \mathrm{MHz}, \mathrm{CDCl}_{3}\right): \delta$ $5.13\left(1 \mathrm{H}, \mathrm{bt}, J=9.4 \mathrm{~Hz}, \mathrm{H}-3^{\prime}\right), 4.99\left(1 \mathrm{H}, \mathrm{bt}, J=9.8 \mathrm{~Hz}, \mathrm{H}-4^{\prime}\right)$, $4.89\left(1 \mathrm{H}, \mathrm{bt}, J=8.4 \mathrm{~Hz}, \mathrm{H}-2^{\prime}\right), 4.53\left(1 \mathrm{H}, \mathrm{d}, J=7.8 \mathrm{~Hz}, \mathrm{H}-\mathrm{1}^{\prime}\right)$, 4.18-3.95 (3H, overlapped, $\left.\mathrm{H}_{2}-1, \mathrm{H}-2\right) 3.72-3.51(5 \mathrm{H}$, overlapped, $\left.\mathrm{H}_{2}-6^{\prime}, \mathrm{H}-5^{\prime}, \mathrm{H}_{2}-3\right), 2.00(3 \mathrm{H}, \mathrm{s}, \mathrm{OAc}), 1.97(3 \mathrm{H}$, $\mathrm{s}, \mathrm{OAc}), 1.94(3 \mathrm{H}, \mathrm{s}, \mathrm{OAc}), 1.92(3 \mathrm{H}, \mathrm{s}, \mathrm{OAc}), 1.35(3 \mathrm{H}, \mathrm{s}$, $\left.\mathrm{CH}_{3}\right), 1.30\left(3 \mathrm{H}, \mathrm{s}, \mathrm{CH}_{3}\right)$; HRESIMS $m / z: 485.1641[\mathrm{M}+\mathrm{Na}]^{+}$ (calcd for $\mathrm{C}_{20} \mathrm{H}_{30} \mathrm{O}_{12} \mathrm{Na}$, 485.1635).

1,2-Di-O-stearoyl-3-O- $\beta$-D-glucosyl- $R$-glycerol. ${ }^{1} \mathrm{H}$ NMR $\left(400 \mathrm{MHz}, \mathrm{CDCl}_{3}\right): \delta 5.25(1 \mathrm{H}, \mathrm{m}, \mathrm{H}-2), 4.34(1 \mathrm{H}$, $\mathrm{dd} J=2.7,12.0 \mathrm{~Hz}, \mathrm{H}-1 \mathrm{a}), 4.26\left(1 \mathrm{H}, \mathrm{d}, J=7.5 \mathrm{~Hz}, \mathrm{H}-1^{\prime}\right), 4.10$ $(1 \mathrm{H}, \mathrm{dd}, J=6.7,12.0 \mathrm{~Hz}, \mathrm{H}-1 \mathrm{~b}), 3.87(1 \mathrm{H}, \mathrm{dd}, J=5.9,11.0 \mathrm{~Hz}$, $\mathrm{H}-3 \mathrm{a}), 3.77\left(2 \mathrm{H}\right.$, overlapped, $\left.\mathrm{H}_{2}-6^{\prime}\right), 3.67(1 \mathrm{H}, \mathrm{dd}, J=5.9,11.0$ $\mathrm{Hz}, \mathrm{H}-3 \mathrm{~b}), 3.47\left(1 \mathrm{H}, \mathrm{bt}, J=8.9 \mathrm{~Hz}, \mathrm{H}-3^{\prime}\right), 3.42(1 \mathrm{H}, \mathrm{bt}, J=8.9$ $\left.\mathrm{Hz}, \mathrm{H}-4^{\prime}\right), 3.25-3.20\left(2 \mathrm{H}\right.$, overlapped, $\left.\mathrm{H}-2^{\prime}, \mathrm{H}-5^{\prime}\right), 2.26(4 \mathrm{H}$, overlapped, $\alpha$-methylenes of acyl portions), $1.58-1.51(4 \mathrm{H}$, overlapped, $\beta$-methylenes of acyl portions), 1.27-1.18 (aliphatic methylenes), $0.83\left(6 \mathrm{H}, \mathrm{bt}, J=6.4 \mathrm{~Hz}, 2 \mathrm{CH}_{3}\right)$;
HRESIMS $m / z: 809.6112[\mathrm{M}+\mathrm{Na}]^{+}\left(\right.$calcd for $\mathrm{C}_{45} \mathrm{H}_{86} \mathrm{O}_{10} \mathrm{Na}$, 809.6119).

1,2-Di-O-stearoyl-3-O-[(2', 3', 4'-tri-O-acetyl-6' -thioacetyl)- $\boldsymbol{\beta}$-D-glucosyl]- $\boldsymbol{R}$-glycerol. ${ }^{1} \mathrm{H}$ NMR $(400 \mathrm{MHz}$, $\left.\mathrm{CDCl}_{3}\right): \delta 5.18-5.11\left(2 \mathrm{H}\right.$, overlapped, $\left.\mathrm{H}-2, \mathrm{H}-3^{\prime}\right), 4.98-4.91$ $\left(2 \mathrm{H}\right.$, overlapped, $\left.\mathrm{H}-4^{\prime}, \mathrm{H}-2^{\prime}\right), 4.47\left(1 \mathrm{H}, \mathrm{d}, J=8.0 \mathrm{~Hz}, \mathrm{H}-1^{\prime}\right)$, $4.27(1 \mathrm{H}, \mathrm{dd}, J=3.8,12.0 \mathrm{~Hz}, \mathrm{H}-1 \mathrm{a}), 4.07(1 \mathrm{H}, \mathrm{dd}, J=6.3,12.0$ $\mathrm{Hz}, \mathrm{H}-1 \mathrm{~b}), 3.90(1 \mathrm{H}, \mathrm{dd}, J=4.9,11.0 \mathrm{~Hz}, \mathrm{H}-3 \mathrm{a}), 3.65(1 \mathrm{H}, \mathrm{dd}, J$ $=5.6,11.0 \mathrm{~Hz}, \mathrm{H}-3 \mathrm{~b}), 3.62\left(1 \mathrm{H}, \mathrm{m}, \mathrm{H}-5^{\prime}\right), 3.24(1 \mathrm{H}, \mathrm{dd}, J=2.7$, $\left.14.0 \mathrm{~Hz}, \mathrm{H}-6^{\prime} \mathrm{a}\right), 3.05\left(1 \mathrm{H}, \mathrm{dd}, J=6.9,14.0 \mathrm{~Hz}, \mathrm{H}-6^{\prime} \mathrm{b}\right), 2.33$ $(3 \mathrm{H}, \mathrm{s}, \mathrm{SAc}), 2.32-2.26(4 \mathrm{H}$, overlapped, $\alpha$-methylenes of acyl portions), $2.10-1.98(9 \mathrm{H}, \mathrm{s}, 3 \mathrm{OAc}), 1.63-1.56(4 \mathrm{H}, \mathrm{m}, \beta-$ methylenes of acyl portions), $1.32-1.20$ (aliphatic methylenes), $0.87\left(6 \mathrm{H}, \mathrm{bt}, J=6.5 \mathrm{~Hz}, 2 \mathrm{CH}_{3}\right)$; HRESIMS $m / z: 993.6321[\mathrm{M}+$ $\mathrm{Na}]^{+}$(calcd for $\mathrm{C}_{53} \mathrm{H}_{94} \mathrm{NaO}_{13} \mathrm{~S}, 993.6313$ ).

1,2-Di-O-stearoyl-3-O-[(2',3', $4^{\prime}$-tri-O-acetyl-6'-iodo)$\beta$-D-quinovosyl]-R/S-glycerol (4). Iodine (49 mg, 0.191 $\mathrm{mmol})$ was added to a mixture of 1,2-distearoyl-3-O- $\beta$-Dglucosyl glycerol $(100 \mathrm{mg}, 0.127 \mathrm{mmol})$, triphenylphosphine (50 mg, $0.191 \mathrm{mmol}$ ), and 2,6-dimethylpyridine $(450 \mathrm{mg}, 4.2$ $\mathrm{mmol}$ ) at temperature of $80{ }^{\circ} \mathrm{C}$; the mixture was stirred for 30 min at $80^{\circ} \mathrm{C}$ and subsequently acetylated by addition of pyridine $(0.5 \mathrm{~mL})$ and acetic anhydride $(0.5 \mathrm{~mL})$; after evaporation of the solvent under a stream of nitrogen, the mixture was purified by silica gel chromatography using a gradient of petroleum ether/ diethylether to give compound 4 (195 mg, $0.191 \mathrm{mmol}, 100 \%$ ) as a colorless oil; ${ }^{1} \mathrm{H}$ NMR $\left(400 \mathrm{MHz}, \mathrm{CDCl}_{3}\right): \delta 5.21-5.16$ (2H, overlapped, $\left.\mathrm{H}-2, \mathrm{H}-3^{\prime}\right), 4.99-4.94\left(1 \mathrm{H}, \mathrm{m}, \mathrm{H}-2^{\prime}\right), 4.87(\mathrm{t}$, $J=8.03 \mathrm{~Hz}, \mathrm{H}-4^{\prime}$ ), 4.56 and 4.55 (each $1 \mathrm{H}, \mathrm{d}, J=8.1 \mathrm{~Hz}, \mathrm{H}-1^{\prime}$ of the two epimers), $4.33-428(1 \mathrm{H}, \mathrm{m}, \mathrm{H}-1 \mathrm{a}), 4.17-4.09(1 \mathrm{H}, \mathrm{m}$, 
$\mathrm{H}-1 \mathrm{~b}), 4.02-3.97$ (1H, m, H-3a), 3.78-3.71 (1H, m, H-3b), $3.52\left(1 \mathrm{H}, \mathrm{m}, \mathrm{H}-5^{\prime}\right), 3.28\left(1 \mathrm{H}, \mathrm{dd}, J=3.06,11.1 \mathrm{~Hz}, \mathrm{H}-6^{\prime} \mathrm{a}\right), 3.13$ $\left(1 \mathrm{H}, \mathrm{dd}, J=8.4,11.1 \mathrm{~Hz}, \mathrm{H}-6^{\prime} \mathrm{b}\right), 2.35-2.26$ (4H, overlapped, $\alpha$ methylenes of stearoyl portions), 2.07-1.97 (9H, s, OAc), $1.64-1.58$ ( $4 \mathrm{H}$, overlapped, $\beta$-methylenes of stearoyl portions), $1.33-1.21(60 \mathrm{H}$, aliphatic methylenes $), 0.91-0.84(6 \mathrm{H}$, overlapped, $\left.2 \mathrm{CH}_{3}\right)$; HRESIMS $m / z: 1045.5460[\mathrm{M}+\mathrm{Na}]^{+}$ (calcd for $\mathrm{C}_{51} \mathrm{H}_{91} \mathrm{NaO}_{12} \mathrm{I}, 1045.5453$ ).

1,2-Distearoyl-3-O-[(2',3', $4^{\prime}$-tri-acetyl-6' -thioacetyl)$\boldsymbol{\beta}$-D-glucosyl]-R/S-glycerol (5). 1,2-distearoyl-3-O-[(2',3',4' tri-acetyl-6'-iodo)- $\beta$-D-glucosyl]-glycerol (4) (170 mg, 0.166 mmol) was dissolved in 2-butanone $(15 \mathrm{~mL})$ and potassium thioacetate $(94 \mathrm{mg}, 0.830 \mathrm{mmol})$. The reaction mixture was stirred at $80{ }^{\circ} \mathrm{C}$ for $2 \mathrm{~h}$, and then, the solvent was evaporated under reduced pressure. The resulting material was purified by silica gel chromatography using a light petroleum ether/diethyl ether gradient to give 1,2-distearoyl-3-O- $\left[\left(2^{\prime}, 3^{\prime}, 4^{\prime}\right.\right.$-tri-acetyl- $6^{\prime}$ thioacetyl)- $\beta$-D-glucosyl $]$-glycerol (161 mg, $0.166 \mathrm{mmol}, 100 \%)$ as a colorless oil; ${ }^{1} \mathrm{H}$ NMR $\left(400 \mathrm{MHz}, \mathrm{CDCl}_{3}\right): \delta 5.20-5.14$ (2H, m, H-2, H-3' ), 4.96-4.89 (2H, m, H-2' , H-4' ), $4.50(1 \mathrm{H}$, d, $\left.J=8.0 \mathrm{~Hz}, \mathrm{H}-1^{\prime}\right), 4.28$ (1H, dd, $\left.J=4.1,11.8 \mathrm{~Hz}, \mathrm{H}-1 \mathrm{a}\right), 4.09$ $(1 \mathrm{H}, \mathrm{dd}, J=5.7,11.8 \mathrm{~Hz}, \mathrm{H}-1 \mathrm{~b}), 3.91(1 \mathrm{H}, \mathrm{dd}, J=4.5,11.1 \mathrm{~Hz}$, $\mathrm{H}-3 \mathrm{a}), 3.65$ (1H, dd, $J=5.4,11.1 \mathrm{~Hz}, \mathrm{H}-3 \mathrm{~b}), 3.62\left(1 \mathrm{H}, \mathrm{m}, \mathrm{H}-5^{\prime}\right)$, 3.25 (1H, bd, $\left.J=11.4 \mathrm{~Hz}, \mathrm{H}-6^{\prime} \mathrm{a}\right), 3.06(1 \mathrm{H}, \mathrm{dd}, J=2.4 \mathrm{~Hz}, 11.4$ $\mathrm{Hz}$ ), 2.35 (3H, s, SAc), 2.33-2.29 (4H, m, $\alpha$-methylene of stearoyl portion), 2.13-1.99 (9H, s, 3OAc), 1.64-1.57 (4H, m, $\beta$-methylene of stearoyl portion), $1.32-1.23(60 \mathrm{H}$, aliphatic methylenes), $0.93-0.87$ (6H, overlapped, $\left.2 \mathrm{CH}_{3}\right)$; HRESIMS $m / z: 993.6329[\mathrm{M}+\mathrm{Na}]^{+}$(calcd for $\mathrm{C}_{53} \mathrm{H}_{94} \mathrm{O}_{13} \mathrm{NaS}$, 993.6313).

Sulfavant S (2). White solid; ${ }^{1} \mathrm{H}$ NMR (400 MHz, $\mathrm{CD}_{3} \mathrm{OD} /$ $\mathrm{CDCl}_{3}$ 1/1): $\delta$ values are referred to $\mathrm{CHD}_{2} \mathrm{OD}$ (3.34 and 49.0 ppm): 5.28 (1H, m, H-2), $4.40(1 \mathrm{H}, \mathrm{dd}, J=2.7,12.0 \mathrm{~Hz}, \mathrm{H}-1 \mathrm{a})$, $4.31\left(1 \mathrm{H}, \mathrm{d}, J=7.6 \mathrm{H}^{-1}{ }^{\prime}\right), 4.24(1 \mathrm{H}, \mathrm{dd}, J=6.9,12.0 \mathrm{~Hz}, \mathrm{H}-1 \mathrm{~b})$, $4.05(1 \mathrm{H}, \mathrm{dd}, J=5.4,11.0 \mathrm{~Hz}, \mathrm{H}-3 \mathrm{a}), 3.79-3.71(3 \mathrm{H}, \mathrm{H}-3 \mathrm{~b}, \mathrm{H}-$ $\left.3^{\prime}, \mathrm{H}-4^{\prime}\right), 3.41$ (1H, bt, $\left.J=8.9 \mathrm{~Hz}, \mathrm{H}-2^{\prime}\right), 3.26$ (1H, H-6'a ), 3.25 $\left(1 \mathrm{H}, \mathrm{H}-5^{\prime}\right), 3.09$ (1H, dd, $\left.J=7.2,15.7 \mathrm{~Hz}, \mathrm{H}-6^{\prime} \mathrm{b}\right), 2.36-2.27$ (4H, $\alpha$-methylenes of stearoyl portions), $1.65-1.56(4 \mathrm{H}, \beta$ methylenes of stearoyl portions), $1.36-1.20(60 \mathrm{H}$, aliphatic methylenes $), 0.89\left(6 \mathrm{H}, \mathrm{bt}, J=6.0 \mathrm{~Hz}, 2 \mathrm{CH}_{3}\right) ;{ }^{13} \mathrm{C}$ NMR $(100$ $\left.\mathrm{MHz}, \mathrm{CD}_{3} \mathrm{OD} / \mathrm{CDCl}_{3} 1 / 1\right): \delta 174.1,173.7$ (C, acyl esters of stearoyl part), $103.2\left(\mathrm{CH}, \mathrm{C}^{\prime}\right), 76.1\left(\mathrm{CH}, \mathrm{C}^{\prime}\right), 73.8(\mathrm{CH}$, $\left.\mathrm{C5}^{\prime}\right), 72.4\left(\mathrm{CH}, \mathrm{C}^{\prime}\right), 72.3\left(\mathrm{CH}, \mathrm{C}^{\prime}\right), 70.2$ (CH, C2), 68.2 $\left(\mathrm{CH}_{2}, \mathrm{C} 3\right), 63.2\left(\mathrm{CH}_{2}, \mathrm{C} 1\right), 53.6\left(\mathrm{CH}_{2}, \mathrm{C6}^{\prime}\right), 34.2\left(\mathrm{CH}_{2}, \alpha-\right.$ methylene of stearoyl portion $), 32.2-29.0\left(\mathrm{CH}_{2}\right.$, methylenes of stearoyl portion), 24.9 ( $\mathrm{CH}_{2}, \beta$-methylene of stearoyl portion), $13.8\left(\mathrm{CH}_{3}\right.$, methyls of stearoyl portion); HRESIMS $\mathrm{m} / z$ : 849.5772 [M - K $]^{-}$(calcd for $\mathrm{C}_{45} \mathrm{H}_{85} \mathrm{O}_{12} \mathrm{~S}^{-}, 849.5767$ ).

Sulfavant R (3). White solid; ${ }^{1} \mathrm{H}$ NMR (400 MHz, $\mathrm{CD}_{3} \mathrm{OD} /$ $\mathrm{CDCl}_{3}$ 1/1): $\delta$ values are referred to $\mathrm{CHD}_{2} \mathrm{OD}$ at 3.34 and 49.0 ppm): $\delta 5.28(1 \mathrm{H}, \mathrm{m}, \mathrm{H}-2), 4.45(1 \mathrm{H}, \mathrm{dd}, J=2.6,12.1 \mathrm{~Hz}, \mathrm{H}-$ 1a), $4.31\left(1 \mathrm{H}, \mathrm{d}, J=7.7 \mathrm{~Hz}, \mathrm{H}-1^{\prime}\right), 4.17(1 \mathrm{H}, \mathrm{dd}, J=6.7,12.1 \mathrm{~Hz}$, $\mathrm{H}-1 \mathrm{~b}), 4.05(1 \mathrm{H}, \mathrm{dd}, J=5.2,11.1 \mathrm{~Hz}, \mathrm{H}-3 \mathrm{a}), 3.78-3.71(3 \mathrm{H}$, overlapped, H-3b, H-3' $\left.{ }^{\prime}, \mathrm{H}-4^{\prime}\right), 3.40\left(1 \mathrm{H}, \mathrm{bt}, J=8.7 \mathrm{~Hz}, \mathrm{H}-2^{\prime}\right)$, $3.26\left(1 \mathrm{H}, \mathrm{H}-5^{\prime}\right), 3.24$ (1H, H-6'a), $3.09(1 \mathrm{H}, \mathrm{dd}, J=7.2,15.7$ $\left.\mathrm{Hz}, \mathrm{H}-6^{\prime} \mathrm{b}\right), 2.35-2.29$ (4H, $\alpha$-methylenes of stearoyl portions), $1.64-1.57$ ( $4 \mathrm{H}, \beta$-methylenes of stearoyl portions), $1.32-1.22$ $(60 \mathrm{H}$, aliphatic methylenes $), 0.88\left(6 \mathrm{H}, \mathrm{bt}, J=6.9 \mathrm{~Hz}, 2 \mathrm{CH}_{3}\right)$; ${ }^{13} \mathrm{C}$ NMR (100 MHz, $\left.\mathrm{CD}_{3} \mathrm{OD} / \mathrm{CDCl}_{3} 1 / 1\right): \delta 174.0,173.8(\mathrm{C}$, acyl esters of stearoyl part), $103.1\left(\mathrm{CH}, \mathrm{C}^{\prime}\right), 76.3\left(\mathrm{CH}, \mathrm{C}^{\prime}\right)$, $73.5\left(\mathrm{CH}, \mathrm{C5}^{\prime}\right), 72.3\left(\mathrm{CH}, \mathrm{C}^{\prime}\right), 72.2\left(\mathrm{CH}, \mathrm{C}^{\prime}\right), 70.5(\mathrm{CH}$, C2), 68.1 ( $\left.\mathrm{CH}_{2}, \mathrm{C} 3\right), 63.1\left(\mathrm{CH}_{2}, \mathrm{C} 1\right), 53.2\left(\mathrm{CH}_{2}, \mathrm{C}^{\prime}\right), 34.1$ $\left(\mathrm{CH}_{2}, \alpha\right.$-methylene of stearoyl portion $), 32.5-29.2\left(\mathrm{CH}_{2}\right.$, methylenes of stearoyl portion), $24.8\left(\mathrm{CH}_{2}, \beta\right.$-methylene of stearoyl portion), 13.7 ( $\mathrm{CH}_{3}$, methyls of stearoyl portion); HRESIMS $m / z: 849.5775[\mathrm{M}-\mathrm{K}]^{-}$(calcd for $\mathrm{C}_{45} \mathrm{H}_{85} \mathrm{O}_{12} \mathrm{~S}^{-}$, 849.5767).

Characterization of Colloidal Nanoparticles. After purification by high-performance liquid chromatography, samples were prepared in $1 \mathrm{~mL}$ of Millipore water at $0.2 \mathrm{mM}$ $(170 \mu \mathrm{g})$ of each compound. After sonication for $40 \mathrm{~min}$ at 35 ${ }^{\circ} \mathrm{C}$, the solutions were maintained at room temperature $\left(20^{\circ} \mathrm{C}\right)$ for $24 \mathrm{~h}$. The mean diffusion coefficient was obtained as an average of at least three measurements at $25{ }^{\circ} \mathrm{C}$. Stability of the systems over time ( 1 week) was systematically controlled by the reproducibility of the diffusion coefficients.

\section{ASSOCIATED CONTENT}

\section{S Supporting Information}

The Supporting Information is available free of charge on the ACS Publications website at DOI: 10.1021/acsomega.8b03304.

Experimental procedures including DLS, human monocytes-DC differentiation, cell staining and stimulation, real-time PCR analysis, cytotoxic assay on moDCs, and surface tension measures; flow-cytometry analysis of maturation phenotyping markers in moDCs stimulated with Sulfavants in different concentrations; and copies of ${ }^{1} \mathrm{H}$ NMR spectra of compounds $\mathbf{2 - 5}$, as well as copies of

${ }^{13} \mathrm{C}$ NMR spectra of compounds 2 and 3 (PDF)

\section{AUTHOR INFORMATION}

\section{Corresponding Authors}

*E-mail: emanzo@icb.cnr.it (E.M.).

*E-mail: afontana@icb.cnr.it (A.F.).

ORCID

Emiliano Manzo: 0000-0002-7394-020X

Genoveffa Nuzzo: 0000-0001-7065-2379

Angelo Fontana: 0000-0002-5453-461X

\section{Author Contributions}

"E.M. and C.G. contributed equally.

\section{Funding}

This study was carried out in the frame of the project "Antigens and adjuvants for vaccines and immunotherapy" (PON01_00117) funded by the National Operational Program for Research and Competitiveness 2007-2013.

Notes

The authors declare no competing financial interest.

\section{ACKNOWLEDGMENTS}

A.F. thanks BioSEArch SRL for the generous support.

\section{REFERENCES}

(1) Aguilar, J. C.; Rodríguez, E. G. Vaccine adjuvants revisited. Vaccine 2007, 25, 3752-3762.

(2) Tritto, E.; Mosca, F.; De Gregorio, E. Mechanism of action of licensed vaccine adjuvants. Vaccine 2009, 27, 3331-3334.

(3) Rappuoli, R.; Mandl, C. W.; Black, S.; De Gregorio, E. Vaccines for the twenty-first century society. Nat. Rev. Immunol. 201 1, 11, 865-872.

(4) Olafsdottir, T.; Lindqvist, M.; Harandi, A. M. Molecular signatures of vaccine adjuvants. Vaccine 2015, 33, 5302-5307.

(5) Xu, F.; Valiante, N. M.; Ulmer, J. B. Small molecule immunopotentiators as vaccine adjuvants. In Vaccine Adjuvants and Delivery Systems; Singh, M., Ed.; John Wiley \& Sons, Inc, 2007; pp 175189.

(6) Egli, A.; Santer, D. M.; Barakat, K.; Zand, M.; Levin, A.; Vollmer, M.; Weisser, M.; Khanna, N.; Kumar, D.; Tyrrell, D. L.; Houghton, M.; 
Battegay, M.; O'Shea, D. Vaccine adjuvants-Understanding molecular mechanisms to improve vaccines. Swiss Med. Wkly. 2014, 144, w13940.

(7) De Gregorio, E.; D’Oro, U.; Wack, A. Immunology of TLRindependent vaccine adjuvants. Curr. Opin. Immunol. 2009, 21, 339345.

(8) Wu, T. Y. H.; Singh, M.; Miller, A. T.; De Gregorio, E.; Doro, F.; D’Oro, U.; Skibinski, D. A. G.; Mbow, M. L.; Bufali, S.; Herman, A. E.; Cortez, A.; Li, Y.; Nayak, B. P.; Tritto, E.; Filippi, C. M.; Otten, G. R.; Brito, L. A.; Monaci, E.; Li, C.; Aprea, S.; Valentini, S.; Calabro, S.; Laera, D.; Brunelli, B.; Caproni, E.; Malyala, P.; Panchal, R. G.; Warren, T. K.; Bavari, S.; O’Hagan, D. T.; Cooke, M. P.; Valiante, N. M. Rational design of small molecules as vaccine adjuvants. Sci. Transl. Med. 2014, 6, $263 \mathrm{ra} 160$.

(9) De Gregorio, E.; Rappuoli, R. From empiricism to rational design: a personal perspective of the evolution of vaccine development. Nat. Rev. Immunol. 2014, 14, 505-514.

(10) Johnson, D. A.; Baldridge, J. R. TLR4 Agonists as vaccine adjuvants; In Vaccine Adjuvants and Delivery Systems; Singh, M., Ed.; John Wiley \& Sons, Inc, 2007; pp 131-156.

(11) Coffman, R. L.; Sher, A.; Seder, R. A. Vaccine adjuvants: Putting innate immunity to work. Immunity 2010, 33, 492-503.

(12) Manzo, E.; Cutignano, A.; Pagano, D.; Gallo, C.; Barra, G.; Nuzzo, G.; Sansone, C.; Ianora, A.; Urbanek, K.; Fenoglio, D.; Ferrera, F.; Bernardi, C.; Parodi, A.; Pasquale, G.; Leonardi, A.; Filaci, G.; De Palma, R.; Fontana, A. A new marine-derived sulfoglycolipid triggers dendritic cell activation and immune adjuvant response. Sci. Rep. 2017, 7,6286 .

(13) Evans, J. T.; Cluff, C. W.; Johnson, D. A.; Lacy, M. J.; Persing, D. H.; Baldridge, J. R. Enhancement of antigen-specific immunity via the TLR4 ligands MPL adjuvant and Ribi.529. Expert Rev. Vaccines 2003, 2, 219-229.

(14) Cluff, C. W. Monophosphoryl lipid A (MPL) as an adjuvant for anti-cancer vaccines: clinical results. Adv Exp Med Biol 2010, 667, 111123.

(15) Baldrick, P.; Richardson, D.; Elliott, G.; Wheeler, A. W. Safety Evaluation of Monophosphoryl Lipid A (MPL): An Immunostimulatory Adjuvant. Regul. Toxicol. Pharmacol. 2002, 35, 398-413.

(16) Kensil, C. R.; Kammer, R. QS-21: a water-soluble triterpene glycoside adjuvant. Expert Opin. Invest. Drugs 1998, 7, 1475-1482.

(17) Kensil, C. R.; Patel, U.; Lennick, M.; Marciani, D. Separation and characterization of saponins with adjuvant activity from Quillaja saponaria Molina cortex. J. Immunol. 1991, 146, 431-437.

(18) Garçon, N.; Van Mechelen, M. Recent clinical experience with vaccines using MPL- and QS-21-containing Adjuvant Systems. Expert Rev. Vaccines 2011, 10, 471-486.

(19) (a) Manzo, E.; Fioretto, L.; Pagano, D.; Nuzzo, G.; Gallo, C.; De Palma, R.; Fontana, A. Chemical synthesis of marine-derived sulfoglycolipids, a new class of molecular adjuvants. Mar. Drugs 2017, 15, 288. (b) Manzo, E.; Ciavatta, M. L.; Pagano, D.; Fontana, A. An efficient and versatile chemical synthesis of bioactive glycoglycerolipids. Tetrahedron Lett. 2012, 53, 879-881.

(20) Traboni, S.; Bedini, E.; Iadonisi, A. Solvent-Free Conversion of Alcohols to Alkyl Iodides and One-Pot Elaborations Thereof. ChemistrySelect 2018, 3, 1616-1622.

(21) Teng, M. W. L.; Bowman, E. P.; McElwee, J. J.; Smyth, M. J.; Casanova, J.-L.; Cooper, A. M.; Cua, D. J. IL-12 and IL-23 cytokines: from discovery to targeted therapies for immune-mediated inflammatory diseases. Nat. Med. 2015, 21, 719-729.

(22) Kaka, A. S.; Foster, A. E.; Weiss, H. L.; Rooney, C. M.; Leen, A. M. Using Dendritic Cell Maturation and IL-12 Producing Capacity as Markers of Function: A Cautionary Tale. J. Immunother. 2008, 31, 359369.

(23) Pearce, E. J.; Everts, B. Dendritic cell metabolism. Nat. Rev. Immunol. 2015, 15, 18-29.

(24) Couper, K. N.; Blount, D. G.; Riley, E. M. IL-10: The Master Regulator of Immunity to Infection. J. Immunol. 2008, 180, 5771-5777.

(25) Owen, S. C.; Doak, A. K.; Ganesh, A. N.; Nedyalkova, L.; McLaughlin, C. K.; Shoichet, B. K.; Shoichet, M. S. Colloidal Drug
Formulations Can Explain "Bell-Shaped" Concentration-Response Curves. ACS Chem. Biol. 2014, 9, 777-784.

(26) Matsumoto, K.; Sakai, H.; Takeuchi, R.; Tsuchiya, K.; Ohta, K.; Sugawara, F.; Abe, M.; Sakaguchi, K. Effective form of sulfoquinovosyldiacyglycerol (SQDG) vesicles for DNA polymerase inhibition. Colloids Surf., B 2005, 46, 175-181.

(27) Yamamoto, Y.; Sahara, H.; Takenouchi, M.; Matsumoto, Y.; Imai, A.; Fujita, T.; Tamura, Y.; Takahashi, N.; Gasa, S.; Matsumoto, K.; Ohta, K.; Sugawara, F.; Sakaguchi, K.; Jimbow, K.; Sato, N. Inhibition of CD62L+ T-cell response in vitro via a novel sulfo-glycolipid, $\beta$-SQAG9 liposome that binds to CD62L molecule on the cell surface. Cell. Immunol. 2004, 232, 105-115.

(28) Aoki, S.; Ohta, K.; Matsumoto, K.; Sakai, H.; Abe, M.; Miura, M.; Sugawara, F.; Sakaguchi, K. An emulsion of sulfoquinovosylacylglycerol with long-chain alkanes increases its permeability to tumor cells. J. Membr. Biol. 2006, 213, 11-18.

(29) Matsumoto, K.; Takenouchi, M.; Ohta, K.; Ohta, Y.; Imura, T.; Oshige, M.; Yamamoto, Y.; Sahara, H.; Sakai, H.; Abe, M.; Sugawara, F.; Sato, N.; Sakaguchi, K. Design of vesicles of 1,2-di-O-acyl-3-O- $(\beta$-dsulfoquinovosyl)-glyceride bearing two stearic acids ( $\beta$-SQDG-C18), a novel immunosuppressive drug. Biochem. Pharmacol. 2004, 68, 23792386.

(30) Pagano, D.; Cutignano, A.; Manzo, E.; Tinto, F.; Fontana, A. Glycolipids synthesis: improved hydrazinolysis conditions for preparation of 1,2-polyunsaturated fatty acyl- $\beta$-monogalactosyl-glycerols. Carbohydr. Res. 2016, 424, 21-23.

(31) Vaccaro, M.; Mangiapia, G.; Paduano, L.; Gianolio, E.; Accardo, A.; Tesauro, D.; Morelli, G. Structural and Relaxometric Characterization of Peptide Aggregates Containing Gadolinium Complexes as Potential Selective Contrast Agents in MRI. ChemPhysChem 2007, 8, $2526-2538$

(32) Bergmann-Leitner, E.; Leitner, W. Adjuvants in the Driver's Seat: How Magnitude, Type, Fine Specificity and Longevity of Immune Responses Are Driven by Distinct Classes of Immune Potentiators. Vaccines 2014, 2, 252-296.

(33) Jacquemet, A.; Lemiègre, L.; Lambert, O.; Benvegnu, T. How the stereochemistry of a central cyclopentyl ring influences the selfassembling properties of archaeal lipid analogues: Synthesis and cryoTEM observations. J. Org. Chem. 2011, 76, 9738-9747.

(34) Jaeger, D. A.; Kubicz-Loring, E.; Price, R. C.; Nakagawa, H. Vesicular Properties of Stereoisomeric Surfactants. Langmuir 1996, 12, 5803-5808.

(35) Aleandri, S.; Bonicelli, M. G.; Bordi, F.; Casciardi, S.; Diociaiuti, M.; Giansanti, L.; Leonelli, F.; Mancini, G.; Perrone, G.; Sennato, S. How stereochemistry affects the physicochemical features of gemini surfactant based cationic liposomes. Soft Matter 2012, 8, 5904.

(36) Bombelli, C.; Stringaro, A.; Borocci, S.; Bozzuto, G.; Colone, M.; Giansanti, L.; Sgambato, R.; Toccaceli, L.; Mancini, G.; Molinari, A. Efficiency of liposomes in the delivery of a photosensitizer controlled by the stereochemistry of a gemini surfactant component. Mol. Pharm. 2010, 7, 130-137.

(37) Fuhrhop, J. H.; Schnieder, P.; Boekema, E.; Helfrich, W. Lipid bilayer fibers from diastereomeric and enantiomeric N-octylaldonamides. J. Am. Chem. Soc. 1988, 110, 2861-2867. 